\title{
The Effect Of Ethical Culture, Leadership Qualities, Entrepreneurship And Innovation On The Performance Of Government Linked Companies
}

\author{
Jamaliah Said, Universiti Teknologi MARA, Malaysia \\ Shamimul Hasan, Universiti Teknologi MARA, Malaysia \\ Hussin Saimin, Universiti Teknologi MARA, Malaysia \\ Normah Omar, Universiti Teknologi MARA, Malaysia
}

\begin{abstract}
Government-linked companies (GLCs) play an essential role in the expansion of the Malaysian economy. GLCs are contributing a significant percentage of the nation's gross capital formation and National Gross Domestic Product and they have been regarded as instruments of national growth and supplementing government's effort in promoting social and economic goals. Nevertheless, the performance of GLCs remains as a major concern. Although much research has been done on organisations and enterprises there is lack of research done on GLCs' performance. Previously, the performance of GLCs in Malaysia has been affected by the poor performance of its key companies such as Proton Holdings Berhad and Malaysia Airline System (MAS). Hence, this study attempts to examine on the effect of ethical culture practices, leadership qualities, entrepreneurship orientation, and innovation existence towards the performance of Malaysian GLCs. In this study, the data is gathered via questionnaires survey collected from 102 state and federal level GLCs. The results of coefficient of independent variables showed that leadership qualities and innovation are positively correlated with organisational performance. This study suggests to improve the performance of GLCs through emphasizing on leadership qualities and placing high emphasis on innovation.
\end{abstract}

Keywords: Government-Linked Companies (GLCs); Performance; Entrepreneurship; Ethical Culture; Leadership Qualities; Innovation

\section{INTRODUCTION}

61 rganisational performance is one of the important factors that shareholders and stakeholders are concerned about. It is considered as an indicator to assess how well the organisation is being operated. A convincing performance boosts up the confidence of shareholders, stakeholders and even potential investors too. The performance of an organisation depends on many factors, for example, ethical culture, leadership qualities, entrepreneurship orientation, innovation, marketing policies, financial policies, human resources, asset efficiency are to name but a few. Government linked companies (GLCs) has a greater role in the economy in Malaysia (Mokhtar, 2005). Government wants to develop the country's economy by transforming GLCs into high-performing entities. In order to achieve this, the Prime Minister of Malaysia has introduced the GLC Transformation Programme ${ }^{1}$ in 2011. Thus, with the investment together with the long term planning implemented by the government, it is expected that the GLCs will be performing well to patronage the market capitalisation besides achieving their commercial objectives. The objectives of GLCs are not only to make profit but also to fulfil their responsibilities to their citizen as well. There are some allegations relating to ethics, leadership, entrepreneurship and innovation against GLCs.

\footnotetext{
${ }^{1}$ GLC Transformation Programme refers to the government's efforts at improving performance in companies under its control or stewardship will have a positive demonstrative effect on the rest of the corporate sector. Undertaking such a program should result in a sustainable lift to the current trajectory of GLC performance, improving Malaysia's ability to achieve Vision 2020. The programme is driven by the Putrajaya Committee on GLC High Performance (PCG) which is chaired by the Prime Minister of Malaysia.
} 
Despite many efforts have been taken by the government for improving the performance of GLCs, there are still numbers of GLCs which are under-performing. According to the overview of 2011 National Audit Report Initiatives \& Updates Related to State Owned Corporations, $28.6 \%$ of the GLCs showed a loss amounting to RM1.720 billion. The National Audit Department indicated that eleven number of GLCs were suffered a loss for the year ended 2008 until 2010. The losses were due to several factors including the unsuccessful of business strategy. These problems occurred due to lack of business expertise and their investment decisions were not economically represented (Mokhtar, 2005). As a result, the companies were not able to perform well in order to achieve the targeted objectives.

These few issues have made the public wonder on ethical culture, leadership qualities, entrepreneurial ownership and innovation. The issue is that some GLCs may have shown good performance with the intervention of the government while others may not. The weaknesses on complying with certain standards, stipulated by the top management, may be one of the causes of not performing as expected. One of the most important factors is the ability of GLCs to enhance performance. However, there is less empirical research on the examination of factors which may contribute to the performance of GLCs. There is a research gap and this study strives to fill this research gap. This study aims to examine factors such as ethical culture, leadership qualities, entrepreneurship orientation, and innovation on the performance of GLCs in Malaysia. This study also aims to contribute to the body of knowledge and to help stakeholders and public in seeking for a better and clearer picture on how these GLCs are performing their operations.

The next section presents a literature review, and this is followed by a description of the model, methodology, the results and discussion, and the conclusion.

\section{LITERATURE REVIEW}

Ethical culture $(E C)$ is the perceived conditions in the organisational context that stimulates employees to behave ethically. Trevino and Weaver (2003) defined ethical culture as those aspects that stimulate ethical conduct. Unethical conduct occurs when employees suffer from lack of adequate or sufficient time, budgets, equipment, information, and authority to fulfil their responsibilities (Kaptein, 2008). Business ethics might have a positive influence on financial performance or vice-versa where it has become an open research question (Berrone et al., 2007). Friedman (1970), Jensen (2001), and Schwab (1996) state that the only social task of the organisation is to maximise shareholders' value while complying with the rules of the market. These scholars argue that ethical investments are in conflict with the profit oriented strategies of the organisation. Rockness and Rockness (2005) mention that the US Sarbanes Oxley legislation, which imposed stern penalties for unethical conduct, recommends that market incentives are highly unpredictable. In contra, Jones (1995), and Jones and Wicks (1999) claim that proactive ethical cultures has a positive impact on performance by creating intangible assets that are very important for long run ventures. Hosmer (1994) also suggests that intangible assets such as trust, commitment and good reputation are generated via a strong ethical standpoint. Further, Fombrun et al. (2000) agree that the act of behaving ethically, an organisation generates intangible gains that improve its capability to attract resources, building up competitive advantages, and advance performance as well as fulfilling the goals of its stakeholders'. Berrone et al. (2007) suggest that corporate ethical identity (CEI) has a positive effect on stakeholders' satisfaction as they believe that the organisation is fulfilling their ethical demands. The organisation increases the level of satisfaction of stakeholders' by addressing the stakeholders' ethical demands. Consequently, they are willing to provide more capital and efforts which leads to enhance performance of the organisation. As such the following hypothesis could be formulated to test the relationship between ethical culture and firm performance.

H1: There is a significant relationship between ethical culture and performance of GLCs.

Good governance provides strong leadership qualities and enhances reliable judgement which ensures that an organisation's resources are used in the most effective way to assist the people and causes its set up for benefit (Driscoll, 2011). According to traditional view, leaders with good qualities has a major critical impact on the performance of the organisation Hall (1997). However, this view has been argued by the contextualists who mainly emphasize on the situational factor as a restriction that leaders face. The arguments are rested after identifying that leadership who possesses good qualities, do not make any difference (Lieberson and O'connor, 1972). Leaders are restricted to the different types of performance result. They are also constrained by the organisation's size which limited the generation of performance value. Another outcome reveals that consistent differences in performance are 
observed between organisations. The impact of the leaders' qualities towards organisation performance is limited by the size of the organisation rather than anything the leaders possesses or do. However, Lieberson and O'Connor (1972) employed a combined of dependent variables and data analysis that was almost impossible for the leadership qualities variable to take a major role (Hambrick and Mason, 1984). They did not allow leadership qualities variable to enter earlier into the equation where the result generated from the choice of the dependent and independent variables were almost repeated. They stated a key research issue that was to determine the relative importance of leadership qualities and organisational performance. How much variance of organisational performance could be associated to individual's leadership qualities and how are they using their competent quality in dealing with business operation within the organisation? To response this question they got information on earnings, sales, profit margin and period of leader joining the department for 167 major United States publicly owned corporation for years 1946 to 1965 . They used three dependent performance variables namely sales, earnings, and profit margin and four independent variables namely leadership qualities, year, company, and industry in the analysis. The leadership qualities variable represented the influence of leaders during their tenure with the company. The analytical strategy was to link variance for each performance measure to each independent variable which was meant for sequential dispersion of variance.

Based on these studies, it was concluded that leadership qualities had a few or no impact on organisational performance as major performance variance was represented by non-leadership factors. Pearce, Steven, and Perry (1985) noted that the appointment of new presidents in a corporation could make headlines in the business section of the newspapers. On the other hand, Lieberson and O'connor (1972) did not find any relationship between leadership qualities and organisational performance indicators, such as profits. In contrast, Pfeffer and Salancik (1978) argued that studies on the effect of skilful administrators indicated that they represented 10 percent of the organisation performance variance. Thomas (1988) provided consistent and compelling evidence that individual leaders could do make a difference. Hence, the flowing hypothesis is proposed:

H2: There is a significant relationship between leadership qualities and performance of GLCs.

Corporate entrepreneurship is an organisational process that contributes to firm survival and performance (Covin and Slevin, 1989; Drucker, 1985; Lumpkin and Dess, 1996; Miller, 1983; Zahra, 1993). The present research on entrepreneurs has been originated from the work of Joseph Schumpeter (1883-1950) who emphasizes on entrepreneurs who introduce new products or new methods of production, and other innovations are the main agents of economic growth that catalyst performance of economy activity. Further, Schumpeter described entrepreneurship as a process of 'creative destruction', whereby the entrepreneur constantly displaces existing products with new ones. Kemelgor et al., (2002) concluded that entrepreneurial orientation (EO) is characterized by cultural differences. They found significant differences in the intensity of EO between firms as well as a significant correlation between EO and business performance. Past studies have conceptually agreed that firms benefit from placing high emphasised on newness, responsiveness, and a reasonable amount of boldness (Rauch et al., 2004; Lumpkin and Dess, 1996). A group of studies have found firms with strong entrepreneurial orientation perform much better than firms that place less emphasis on an entrepreneurial orientation (Covin \& Slevin, 1989; Hult, Snow, \& Kandemir, 2003; Lee, Lee \& Pennings, 2001; Wiklund \& Shepherd 2003). Another group of studies reported positive but weak relationship between EO and firms' performance (Dimitratos, Lioukas, \& Carter, 2004; Lumpkin \& Dess, 2001; Zahra,1991). However, a group of studies unable to find a positive relationship between EO and performance (George, Wood, \& Khan, 2001; Covin, Slevin, \& Schultz, 1994). These mixed finding warrent more studies to test the relationship between $\mathrm{EO}$ and performance.

Hence, the following hypothesis could be formulated:

H3: There is a relationship between entrepreneurship orientation and performance of GLCs.

As innovation is scaled across the company, it begins simultaneously to fulfil the core business mandate and to support societal goals. Innovation has gained more literature attention in the context of smaller firms (Acs and Audretsch, 1988). Innovation is an advantage for firms which adopt entrepreneurship to gain profit via the impermanent introduction of a monopoly considering the non-stop innovation activity as the main source of long term entrepreneurial success (Schumpeter, 1934). The establishment of innovative services, processes, products or business models innovative products, services, processes, or business models creates to be attractive offer which become extra 
opportunity for SMEs remains competitive (Porter, 1980). SMEs could be beneficial from buyers' brand loyalty and demand sensitivity to price reduction as a consequence of customers' perception towards innovation uniqueness (Lieberman and Montgomery, 1988). Nor Ghani et al., 2016 studied the relationship between innovation and organisation performance and found a positive relationship between innovation and value creation. It was also found that productivity would increase for service companies where it was independent from the level of newness of the innovations. Rosenbusch et al. (2011) studied the relationship between innovation and performance. In the study, they found that innovation has a positive relationship on the performance of SMEs.

Innovation can be considered as valuable for an organization as it enables the production of products or services that satisfy the needs and desires of customers that other competitors fail to fulfill (Ireland, Hoskisson \& Hitt, 2009). Due to the globalization, it is important for an organization to possess products or services that are unique from its competitors (Barney, 1991; Said. et.al, 2016). Through innovation, an organization would be able to produce products or services at an economical cost and satisfy the needs of its customers. This is because innovation would lead the organization to be a step ahead from its competitors (Barney, 1991). Innovation also assists an organization to improve its performance by introducing or upgrading its products or services. In other words, innovation assists an organization to maintain the loyalty of its customers towards its products or services (Rosli \& Sidek, 2013). Hence, the following hypothesis is proposed:

H4: There is a significant relationship between innovation and performance of GLCs

\section{CONCEPTUAL FRAMEWORK}

The visualization of our research idea could be shown in a diagrammatic manner to form a view of a graphical representation of the diagnostic pattern of the problem under study. Figure 1 shows that ethical culture (EC), leadership qualities (LQ), entrepreneurship orientation (EO), and innovation are four construct and each construct has seven (x1 - x7) observed indicators. These constructs are used subsequently as independent variable in this study. Again, corporate performance $(\mathrm{CP})$ is another construct which has eight observed indicators (x1-x8) and this construct is used subsequently as dependent variable. Four alternative hypotheses are drawn in order to examine the influence of independent variable over dependent variable. Hypothesis 1 (H1) is drawn to examine the relationship between ethical culture and performance, hypothesis $2(\mathrm{H} 2)$ is formed to investigate the influence of leadership qualities on corporate performance, hypothesis $3(\mathrm{H} 3)$ is developed to measure the impact of entrepreneurship orientation on corporate performance and hypothesis $4(\mathrm{H} 4)$ is established to examine the linear relationship between innovation and corporate performance. 
Figure 1. The relationship between ethical culture, leadership qualities, entrepreneurship, innovation and corporate performance

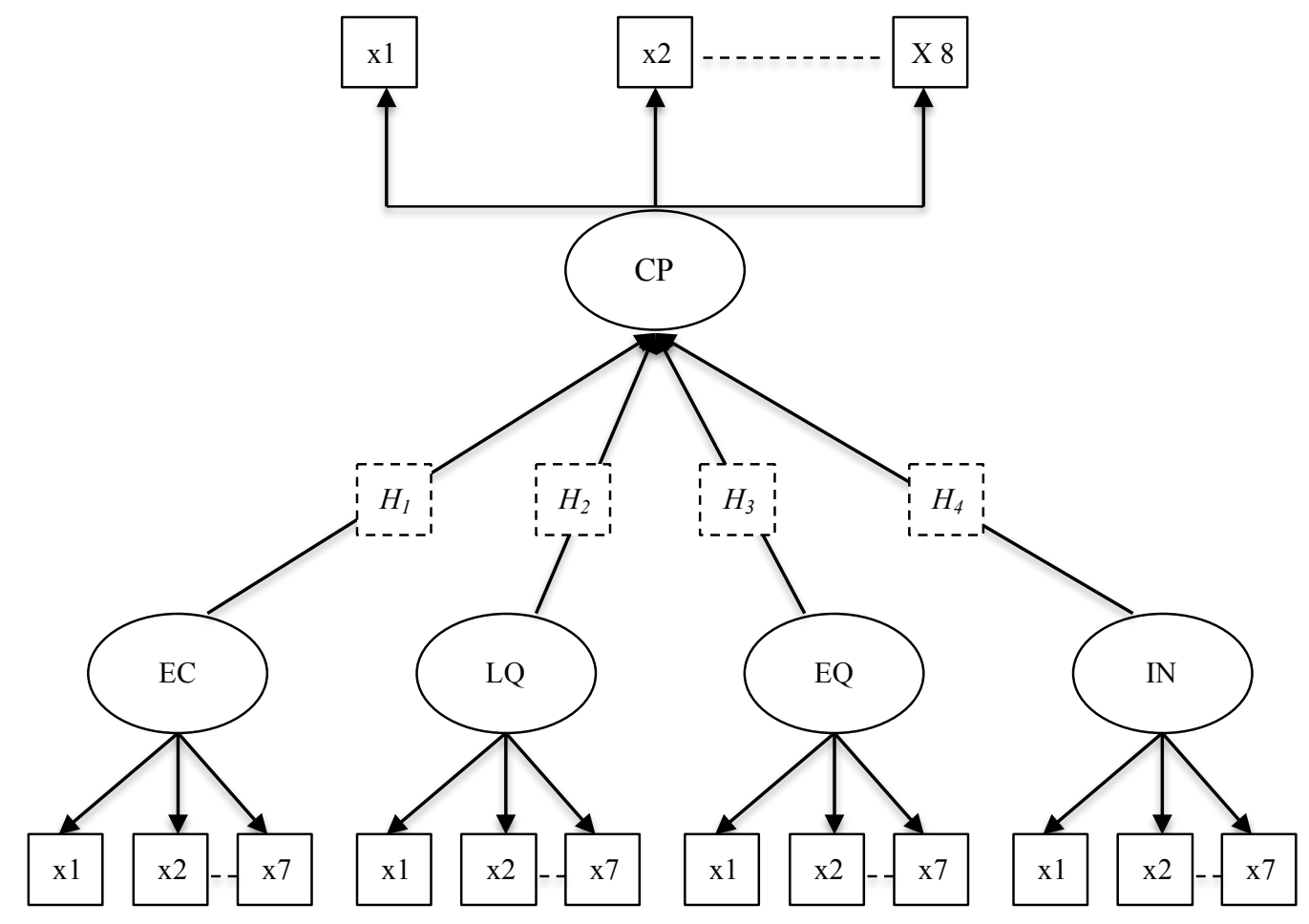

RESEARCH APPROACH

\section{Data}

Structured questionnaires were designed for collecting primary data through a survey among accountant, accounts manager, or equivalent designations of all (401 companies) GLCs. In the questionnaire, seven specific questions (x1$\mathrm{x} 7$ ) were developed for measuring each of four constructs such as ethical culture, leadership qualities, entrepreneurship orientation and innovation and eight specific questions (x1 - x8) were developed for measuring another construct i.e., corporate performance (Appendix 1). These questions were selected from previous literatures. A seven point Likert scale that ranged from 1 (strongly disagree) to 7 (strongly agree) was used to measure the four above constructs and another Likert scale that ranged from 1 (much worse) to 7 (much better) was used to measure the corporate performance construct. Finally, 102 respondents participated in the survey which is 25.5 percent of the population. Sufficient sample size could be measured using two conditions. 1). 15 participants per predictor and 2). Using the formula: $\mathrm{N}>50+8 \mathrm{~m}$. The ' $\mathrm{m}$ ' indicates the number of independent variables and the ' $\mathrm{N}$ ' indicates the total number of sample. The number of participants in this study is $102>15$ per predictor and hence the first condition is satisfied. The calculated total sample size should be more than $82(=50+8 * 4)$ participants. The actual sample size is 102 , which is more than 82 and therefore the second condition is also satisfied. This sample size allows us to generalise the results of this study.

\section{Methods}

The analyses in this study were divided into two phases such as measurement of construct phase and hypotheses testing phase. Cronbach's alpha, Eigen values, Kaiser-Meyer-Olkin (KMO), Bartlett's Test of sphericity, and confirmatory factor analysis (CFA) were under measurement phase. These values of constructs were saved as variables to test the hypotheses. Test of normality of variables (skewness and kurtosis), bi-variate analysis (correlation matrix), ANOVA (F test), and multiple regressions techniques (coefficients of the model) were under hypotheses testing phase. The bivariate analysis was applied to detect multicollinearity problems (if any) between independent variables; 
ANOVA was used for having an overall direction of accepting or rejecting the hypotheses (Hasan et al. 2014); A regression model was developed for this study to estimate the impact of ethical culture, leadership qualities, entrepreneurship orientation and innovation on corporate performance. The matrix of regression model is presented below. Here, the number of rows and the number of column for $\mathrm{Nx} 1$ matrix (Yi) are 102 and 1 respectively. The number of rows and the number of column (constant and Xij variables) for N x P matrix are 102 and 5 respectively. The number of rows and the number of column for Px 1 matrix $(\beta)$ are 5 and 1 respectively. Finally, the number of rows and the number of column for $\mathrm{N} x 1$ matrix ( $\varepsilon i$ ) are 102 and 1 respectively.

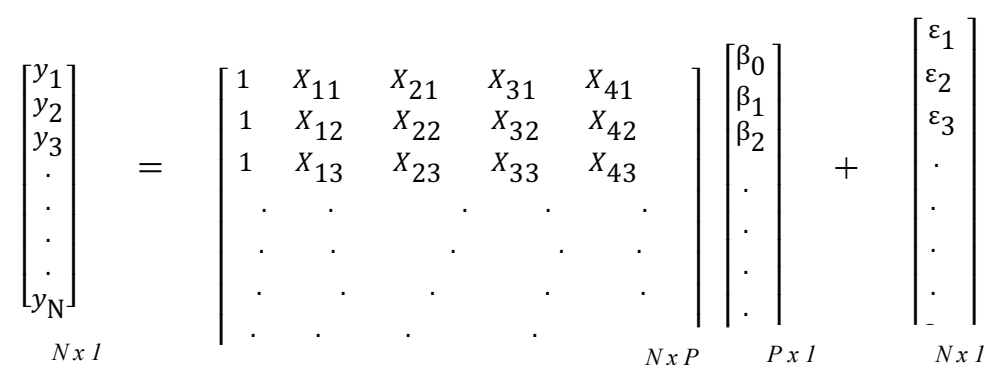

where,

Dependent Variable:

$\mathrm{Yi}=$ Corporate performance as per $\mathrm{i}$ respondents

$\mathrm{i}=1,2,3, \ldots \ldots 102$

Other Notions:

$\mathrm{N}=$ Total number of observed records

$\mathrm{P}=$ Total number of variables including intercept

Independent Variable:

$\mathrm{X} 1=$ Ethical Culture

$\mathrm{X} 2=$ Leadership Qualities

$\mathrm{X} 3=$ Entrepreneurial Orientation

$\mathrm{X} 4=$ Innovation

Regression Parameters"

$\beta 0=$ Intercept of the model

$\beta=$ Regression parameters

The Error Term:

$\varepsilon i=$ The unobserved variables of $i$ respondents

\section{RESULTS AND DISCUSSION}

Table 1 shows the descriptive statistics for five constructs such as ethical culture, leadership qualities, entrepreneurial orientation, innovation and corporate performance. Seven questions were set for each constructs (Appendix A: table 6-9) except corporate performance (Appendix A: table 10) for which eight questions were set. To compare the result for descriptive statistic, mean for each question was obtained first. From the table, the highest mean for ethical culture is question 5 (my organisation makes it sufficiently clear on how to use company equipment responsibly) with a mean of 5.74 and standard deviation of .974 whereby the lowest mean is question 2 (organisation sets a good example in terms of ethical behaviour) with mean of 5.36 and standard deviation of 1.115; for leadership qualities, the question 1 (top management has ultimate responsibility for directing the affairs of the organisation, ensuring it is not a debt, well run and delivering the outcomes for which it has been set up) secured the highest mean at 5.35 with a standard deviation of 1.021 while the question 5 ( top management has ultimate responsibility in finding way to reduce cost of 
production or service) secured the lowest mean at 4.88 with a standard deviation of .904 ; for entrepreneurial orientation, question 5 (actively searching for business opportunities) secured the highest mean at 5.73 with standard deviation of 1.006 and question 3(my organisation has a strong tendency for high risk projects) secured the lowest mean at 5.18 with a standard deviation of 1.227; for innovation, question 6 (my organisation is adopting the introduction process of new products to the existing or new markets, through the combination strategic orientation with innovative behaviour and process) secured the highest mean score at 5.39 with a standard deviation of 0.997 and question 2 (my organisation is adopting a high level of organisation innovativeness) secured the lowest mean at 5.16 with a standard deviation of 1.106; and for corporate performance, question 5 (firm growth) and 6 (profitability) secured the highest mean at 5.92 with standard deviation of 1.069 and 1.216 respectively while question 3 (customer retention) secured the lowest mean at 5.33 with a standard deviation of 1.146 .

Table 1. Summary of Descriptive Statistics

\begin{tabular}{l|c|c|c|c|c|c}
\hline Constructs & Dimensions & Grade & Minimum & Maximum & Mean & St. Dev. \\
\hline \multirow{2}{*}{ Ethical Culture } & EC5 & Highest & 3 & 7 & 5.74 & 0.974 \\
\hline \multirow{2}{*}{ Leadership Qualities } & EC2 & Lowest & 3 & 7 & 5.36 & 1.115 \\
\hline \multirow{2}{*}{ Entrepreneurship Orientation } & LQ1 & Highest & 2 & 7 & 5.35 & 1.021 \\
\cline { 2 - 7 } & LQ5 & Lowest & 3 & 7 & 4.88 & 0.904 \\
\hline \multirow{2}{*}{ Innovation } & EO5 & Highest & 2 & 7 & 5.73 & 1.006 \\
\cline { 2 - 7 } & EO3 & Lowest & 1 & 7 & 5.18 & 1.277 \\
\hline \multirow{2}{*}{ Corporate Performance } & IN6 & Highest & 3 & 7 & 5.39 & 0.997 \\
\cline { 2 - 7 } & IN2 & Lowest & 2 & 7 & 5.16 & 1.106 \\
\hline & CP5 & Highest & 2 & 7 & 5.92 & 1.069 \\
\cline { 2 - 7 } & CP6 & Highest & 1 & 7 & 5.92 & 1.216 \\
\hline
\end{tabular}

The reliability of a scale can vary depending on the sample. It is therefore necessary to check that whether each of scales is reliable with particular sample, outlined in Table 2. One of the most commonly used indicators of internal consistency is Cronbach's alpha coefficient. Ideally, the Cronbach's alpha coefficient of a scale should be above 7 (DeVellis 2003). Cronbach's alpha coefficient of ethical culture, leadership qualities, entrepreneurial orientation, innovation, and corporate performance are $.939>.7, .852>.7, .926>.7, .952>.7$, and $.89>.7$ respectively. So it is clear that the scales are reliable as all Cronbach's alpha for all cases are more than .7.

The suitability of data for factor analysis was assessed in two ways such as Kaiser-Meyer-Olkin (KMO) and Bartlett's Test of Sphericity (Bartlett 1954). The recommended value of KMO is .6 (Kaiser 1970, 1974) and The Chi square value of Bartlett's Test of Sphericity should be statistically significant. The Kaiser-Meyer-Olkin (KMO) values for EC, LQ, EO, IN, and CP are $.939>.6, .852>.6, .926>.6, .952>.6$, and $.890>.6$ respectively. The Bartlett's Test of Sphericity for all constructs is statistically significant at 1 percent level of significance.

Therefore, there was no problem for conducting factor analysis of the constructs. According to the Kaiser's criterion (factor extraction method), only factors with an eigenvalue of 1.0 or more are retained for further investigation. The Eigenvalues of EC, LQ, EO, IN, and CP were $4.863>1.0,3.22>1.0,4.571>1.0,5.21>1.0$ and $4.228>1.0$ respectively.

Table 2. Instrument validation (Reliability and Factor Analysis)

\begin{tabular}{l|c|c|r|r|r}
\hline & EC & LQ & EO & \multicolumn{1}{|c|}{ IN } & \multicolumn{1}{c}{ CP } \\
\hline Cronbach's Alpha & 0.939 & 0.852 & 0.926 & 0.952 & \multicolumn{1}{c}{0.89} \\
\hline Kaiser-Meyer-Olkin of sampling adequacy test & 0.901 & 0.832 & 0.874 & 0.893 & 0.793 \\
\hline Bartlett's Test of Sphericity - Approx. Chi-square & 601.372 & 286.028 & 521.514 & 719.345 & 551.710 \\
\hline Level of Significance & 0.000 & 0.000 & 0.000 & 0.000 & 0.000 \\
\hline Eigenvalue Component 1 & 4.863 & 3.22 & 4.571 & \multicolumn{1}{|c|}{5.21} & 4.228 \\
\hline \% of variance & 69.467 & 46.003 & 65.3 & 74.423 & 36.013 \\
\hline
\end{tabular}


Factor loading shows the connection strength between factors and indicators. Under confirmatory factor analysis there is only one factor and many indicators which are selected from the previous literatures. The relationship between them is measured through factor loading. Seven indicators were used for each of the four constructs such as EC, LQ, EO and IN and eight indicators were used to measure the value of corporate performance (CP). In each case, the connection strength between factor and indicators were very strong. The loading matrix for five constructs is presented in Table 3.

Table 3. Factor Loading Matrix

\begin{tabular}{l|c|c|c|c|c|c|c|c|c|}
\hline & $\mathbf{x 1}$ & $\mathbf{x 2}$ & $\mathbf{x 3}$ & $\mathbf{x 4}$ & $\mathbf{x 5}$ & $\mathbf{x 6}$ & $\mathbf{x 7}$ & $\mathbf{x 8}$ \\
\hline Ethical Culture & 0.895 & 0.814 & 0.811 & 0.793 & 0.865 & 0.781 & 0.868 & nil \\
\hline Leadership Qualities & 0.767 & 0.699 & 0.567 & 0.477 & 0.711 & 0.749 & 0.726 & nil \\
\hline Entrepreneurship Orientation & 0.736 & 0.868 & 0.773 & 0.791 & 0.778 & 0.87 & 0.831 & nil \\
\hline Innovation & 0.877 & 0.88 & 0.829 & 0.914 & 0.874 & 0.896 & 0.76 & nil \\
\hline Corporate Performance & 0.783 & 0.66 & 0.692 & 0.721 & 0.732 & 0.825 & 0.753 & 0.631 \\
\hline
\end{tabular}

A multiple regression was performed to investigate the influence of independent variables (EC, LQ, EO and IN) on dependent variable (CP). Preliminary analyses were conducted to ensure no violation of the assumption of normality, linearity, and homoscedasticity. Additionally, the correlations between predictor variables included in the study were examined. All correlations were weak to moderate, ranging between $r=0.511,<.001$ and $r=0.700, p<.001$. This indicates that multicollinearity was unlikely to be a problem (see Tabachnick and Fidell, 2007). All predictor variables were statistically correlated with corporate performance which indicates that the data was suitably correlated with the dependent variable for examining through multiple regression to be reliably undertaken. The correlation matrix of the variables is presented in Table 4.

Table 4. Correlation Matrix

\begin{tabular}{|c|c|c|c|c|c|}
\hline Variables & EC & LQ & EO & IN & $\mathbf{C P}$ \\
\hline EC & 1 & & & & \\
\hline LQ & $.512^{* *}$ & 1 & & & \\
\hline EO & $.653^{* *}$ & $.511^{* * *}$ & 1 & & \\
\hline IN & $.529^{* *}$ & $.626^{* *}$ & $.700^{* *}$ & 1 & \\
\hline $\mathrm{CP}$ & $.532^{* *}$ & $.799^{* *}$ & $.555^{* *}$ & $.703^{* *}$ & 1 \\
\hline
\end{tabular}

** Correlation is significant at the 0.01 level (2-tailed).

As for the estimation of the regression model, Table 5 shows that the explanatory power of the model is 71 percent (R2) of the variation in corporate performance. The $F$ test (59.463; $p$ value 0.000$)$ revealed that a significant influence of independent variables on dependent variable at 1 percent level of significance was existed. The results of coefficient of independent variables showed that two variables (LQ and IN) had significant influence and the other two (EC) and EO) did not have significant influence on corporate performance. Leadership qualities and innovation have significant relationship with corporate performance at 1 percent level of significance. Ethical culture and entrepreneurship orientation do not have significant relationship even at 10 percent level of significance. The results are presented in the following table. 
Table 5. Estimates of the coefficients of the Model

\begin{tabular}{|c|c|c|c|c|c|c|}
\hline Predictors & Co-efficient ( $\beta$ ) & SE & z-value & p-value & Hypothesis & Results \\
\hline EC & 0.081 & 0.07 & 1.079 & 0.283 & $\mathrm{H}_{1}$ & Reject \\
\hline LQ & 0.566 & 0.085 & 7.767 & 0.000 & $\mathrm{H}_{2}$ & Failed to reject \\
\hline $\mathrm{EO}$ & -0.003 & 0.082 & -0.035 & 0.972 & $\mathrm{H}_{3}$ & Reject \\
\hline IN & 0.308 & 0.081 & 3.62 & 0.000 & $\mathrm{H}_{4}$ & Failed to reject \\
\hline \multicolumn{3}{|c|}{ SE Regression } & & \multicolumn{2}{|c|}{0.46756} & \\
\hline \multicolumn{3}{|c|}{ o } & & \multicolumn{2}{|c|}{0.843} & \\
\hline \multicolumn{3}{|l|}{$\mathrm{R}^{2}$} & & \multicolumn{2}{|r|}{0.71} & \\
\hline \multicolumn{3}{|l|}{ Adjusted $\mathrm{R}^{2}$} & & \multicolumn{2}{|r|}{0.698} & \\
\hline \multicolumn{3}{|l|}{ F-value } & & \multicolumn{2}{|r|}{59.463} & \\
\hline \multicolumn{3}{|l|}{ P-Value } & & \multicolumn{2}{|r|}{0.000} & \\
\hline \multicolumn{3}{|l|}{ DF - Model } & & \multicolumn{2}{|r|}{4} & \\
\hline \multicolumn{3}{|l|}{ DF - Residual } & & \multicolumn{2}{|r|}{97} & \\
\hline
\end{tabular}

\begin{tabular}{l|l} 
EC & Ethical culture \\
\hline LQ & Leadership qualities \\
\hline EO & Entrepreneurship orientation \\
\hline $\mathrm{IN}$ & Innovation \\
\hline $\mathrm{R}^{2}$ & The explanatory power of regression equation \\
\hline
\end{tabular}

The coefficient indicates the direction of the relationship (positive for same direction and negative for opposite direction) between predictors and response variable. P-value indicates the level of significance in other words it tells us the confidence level of the results. The coefficients of ethical culture, leadership qualities, entrepreneurship orientation and innovation are $0.081,0.566,-0.003$, and 0.308 respectively. The $p$ values of ethical culture, leadership qualities, entrepreneurship orientation and innovation are $0.283,0.000,0.972$, and 0.000 respectively. Ethical culture (EC) does not have significant influence on corporate performance and also has a little but positive degree of influence. This result does not support the hypothesis (H1) about the significant linear relationship between ethical culture and corporate performance. This result indicates that management are currently unaware of practicing ethical culture for corporate performance. Leadership qualities (LQ) have a positive and high degree of influence on corporate performance at 1 percent level of significance. The result failed to reject the hypothesis 2 (H2). This results match with previous findings (Parry and Proctor-Thomson, 2002; Kotter and Heskett, 1992) but Lieberson and O'connor (1972) did not find significant relationship between leadership qualities and corporate performance. The coefficient of entrepreneurship orientation (EO) was the lowest value and negative. It does not have a significant relationship with corporate performance as well. This study failed to accept the hypothesis 3 (H3) and the result does not match with the previous results such as Zahra (2005). Innovation (IN) has a positive and high degree of influence on corporate performance at 1 percent level of significance. The result failed to reject the hypothesis 4 (H4). This results match with previous findings (Nonaka, 1995).

Leadership qualities and innovation have a greater role in GLCs performance. Policy makers should take right decision while selecting leaders. Selecting the right person with right qualities and experiences can bring bless for the organisation. The leadership qualities is the most influential factor among four factors as it secured the highest beta value. Leaders who possess good qualities will lead the organisation for success. Good governance provides strong leadership qualities and enhances judgement which ensures the effective use of organisation's resources. The good leadership qualities shown by Malaysian GLCs perhaps have boosted the business activities of the GLCs which indirectly shows overall better performance of the organisation. The innovation is the second most influential factor among four factors as it secured the second highest beta value in this study. Latest and frequent innovations will make the organisation one step ahead from its competitor in producing goods and services. It will make the organisation more competitive in the industry as a whole and as such, the performance of the organisation will also expand. Organisation need innovativeness and also innovative personnel in order to create new products, services and process for future success. In the Malaysian GLCs context perhaps, the good innovations have stimulated the overall performance of the organisation. 


\section{CONCLUSION}

The study concludes that leadership quality and innovation have a greater impact on corporate performance. Ethical culture and entrepreneurial orientation do not have statistical influence on corporate performance at present situation. Policy makers should select a right person with wright qualities and experience including integrity. The leaders should promote the organisation with innovation to retain the existing customers as well as to bring potential customers. The findings of this study provide an indication that GLCs need to utilise talents of their leaders and adopts latest technology in the daily activities and support best innovation of product or services of the organisation. GLCs also need to have a proactive action in introducing products or services to show high level of innovation. The findings provide evidence that performance of GLCs can be enhanced if sufficient levels of financial priorities are taken into consideration. GLCs need to play an important role in seeking for organisation performance foremost so as to contribute to the country's economic development. In addition, ethical culture and entrepreneurial orientation is also important to introduce in the organisation in order to boost up the level of confidence of stakeholders.

Further research may consider of exploring the extent to which the Malaysian GLCs ownership and control structure which increase their overall performance could serve as a model for the-third-world and developing countries.

\section{ACKNOWLEDGEMENT}

The researchers gratefully acknowledge the financial support and generosity of Accounting Research Institute (ARI) and the Ministry of Higher Education, Government of Malaysia without which the present study could not have been completed.

\section{REFERENCES}

Acs, Z.J and Audretsch, D.B. (1988). Innovation in large and small firms: an empirical analysis. American Economic Review, 78(4), 678-690

Ahmed, P. K. (1998). Culture and climate for innovation. European journal of innovation management, 1(1), 30-43.

Barney, J. (1991). Firm Resources and Sustainable Competitive Advantage.Journal of Management, 17(1), 99-120.

Berrone, P., Surroca, J. , \& Tribó, J. A. (2007). Corporate ethical identity as a determinant of firm performance: a test of the mediating role of stakeholder satisfaction. Journal of Business Ethics, 76(1), 35-53.

Bryman, A. E. and Cramer, D. (1997). Quantitative data analysis with SPSS for Windows: A guide for social scientists. New York and London: Routledge.

Bygrave, W.D. (1993). Theory of building in the entrepreurship paradigm. Journal of Small Business Venturing, 8(3), 255-280

Covin, J.G and Slevin, D.P. (1989). Strategic management of small firms in hostile and benign environments. Strategic Management Journal, 10(1), 75-87.

Covin, J. G., Slevin, D. P., \& Schultz, R. L. (1994). Implementing strategic missions: effective strategic, structural, and tactical choices. Journal of Management Studies, 31(4), 481- 503.

Dess, G. G., Lumpkin, G. T., \& Covin, J. G. (1997). Entrepreneurial strategy making and firm performance: Tests of contingency and configurational models. Strategic Management Journal, 18(9), 677-695.

Dimitratos, P., Lioukas, S., \& Carter, S. (2004). The relationship between entrepreneurship and international performance: the importance of domestics environment. International Business Review, 13 (1), 19-41.

Driscoll, L. (2011). Time of evoluktion [Governance of voluntary and community organization]. Keeping Good Companies, 63 (7), 407-409.

Drucker, P.F. (1985) “The Practice of Innovation”, Innovation and Entrepreneurship Practice and Principles, Harper \& Row, New York, pp. 19-33

Fombrun, C.J., Gardberg, N.A., and Barnett, M.L. (2000). Opportunity platforms and safety nets: corporate citizenship and reputational risk. Business and Society Review, 105(1), 85-106

Friedman, M. (1970). The social responsibility of business is to increase its profits. New York Times Magazine, 13, 32-33.

George, G., Wood, D. R. Jr, and Khan, R. (2001). Networking strategy of boards: implications for small and medium-sized enterprises. Entrepreneurship-and-Regional-Development, 13(3), 269-285.

Hall, R.H. (1977). Organisations: Structure and Process: NJ: Prentice-Hall.

Hambrick, D.C. \& Mason, P.A. (1984). Upper echelons: The organization as a reflection of its top managers. Academy of Management Review, 9(2), 193-206.

Hasan, M. S., Abdul Rahman, R and Hossain, S. Z. (2014). Monitoring family performance: Family ownership and corporate governance structure in Bangladesh. Procedia Social and Behavioral Sciences, 145: 103- 109.

Hosmer, L. T. (1994). Strategic planning as of ethics mattered. Strategic Management Journal, 15, 17-34. 
Hult, G. T.M, Snow, C.C \& Kandemir, D. (2003). The role of entrepreneurship in building cultural competitiveness in different organizational types. Journal of Management, 29(3), 401-426.

Jensen, M. C. (2001). Value maximization, stakeholder theory, and the corporate objective function. Journal of Applied Corporate Finance, 14(3), 8-21.

Ireland, R., D., Hoskisson, R., E., \&Hitt, M., A., (2009). Understanding Business Strategy: Concepts and Cases. Mason, OH. Thomson Higher Education.

Jones, T. M. (1995). Instrumental stakeholder theory: A synthesis of ethics and economics. Academy of Management Review, 20(2), 404-437

Jones, T. M and Wicks, A. C. (1999). Convergent stakeholder theory. Academy of Management Review, 24(2), $206-221$.

Judge, G., Griffiths, W. E., Hill, R. C., Lutkepohl, H., and Lee, T. C. (1985). The theory and practice and econometrics. NewYork: John Wiley.

Kaptein, Muel. . (2008). Developing and testing a measure for the ethical culture of organizations: The corporate ethical virtues model. Journal of Organizational Behavior, 1-45.

Kemelgor, B. H. (2002). A comparative analysis of corporate entrepreneurial orientation between selected firms in the Nether Land and USA. Entrepreneurship and Regional Development, 14, 67-87.

Kotter, J.P and Heskett, J.L. (1992). Corporate culture and performance. New York: The Free Press.

Lee, C., Lee, K., \& Pennings, J. M. (2001). Internal capabilities, external networks, and performance: a study on technologybased ventures. Strategic Management Journal, 22(6-7), 615-640.

Lieberman, M. B., \& Montgomery, D. B. (1988). First-mover advantages. Strategic management journal, 9(SI), $41-58$.

Lau, Y.W., \& Tong, C. Q. (2008). Are Malaysian government-linked companies (GLCs) creating value? International Applied Economics and Management Letters, 1(1), 9-12.

Lieberson, S, and O'Connor, J. F.1972. Leadership and organizational performance: a study of large corporations. American Sociological Review, 37, 117-130.

Lumpkin, G.T and Dess, G.G. (1996). Clarifying the entrepreneurial orientation construct and linking it to performance. Academy of Management Review, 21,135-172.

Lumpkin, G.T., and Dess, G.G. (2001) Linking two dimensions of entrepreneurial orientation to firm performance: the moderating role of environment and industry life cycle. Journal of Business Venturing, 16 (5), 429-451.

Miller, D. (1983). The correlates of entrepreneurship in three types of firms. Management Science, 29,770-791.

Mokhtar, A. (2005). The Malay way of business change. Economist 376 (8440), 50.

Nonaka, I. (1995). The knowledge-cleating company: How Japanese companies create the dynamics of innovation. Oxford university press, 96-104.

Nor Ghani M. N., Abul Bashar, B \& Said., J (2016). Innovation barriers and risks for food processing SMEs in Malaysia: A logistic regression analysis. Malaysian Journal of Society and Space 12 (2), $167-178$

Parry, K., \& Proctor-Thomson, S. (2002). Leadership, culture and performance: The case of the New Zealand public sector. Journal of Change Management, 3(4), 376-399.

Pearce, J. L., Steveson, W.B., \& Perry, J.L. (1985). Managerial compensation based on organizational performance: a time series analysis of the effects of merit pay. Academy of Management Journal, 28 (2), 261-278.

Pfeffer, J., \& Salancik, G. R. 1978. The external control of organizations: A resource dependence perspective. New York: Harper \& Row.

Porter, M.E. (1980). Competitive strategy: Techniques for analysing industries and competitors. New York: Free Press.

Rauch, A., Wiklund, J., Frese, M. \& Lumpkin, T.G. (2004). Entrepreneurial orientation and business performance: Cumulative empirical evidence. In Bygrave, W.D., Brush, C.G., Davidsson, M.L.P., Meyer, G.D., Fiet, J., Sohl, J., Greene, P. G., Zacharakis, A. and Harrison, R.T. (Eds). Frontiers of Entrepreneurship Research. Wellesley, MS: Babson College.

Rockness, H and Rockness, J. (2005). Legislated ethics: from Enron to Sarbanes Oxley, the impact on corporate America. Journal of Business Ethics, 57 (1), 31-54.

Rosenbusch, N., Brinckmann, J., \& Bausch, A. (2011). Is innovation always beneficial? A meta-analysis of the relationship between innovation and performance in SMEs. Journal of Business Venturing, 26(4), 441-457.

Rosli, M. M., \&Sidek, S. (2013). The Impact of Innovation on the Performance of Small and Medium Manufacturing Enterprises: Evidence from Malaysia. Journal of Innovation Management in Small \& Medium Enterprise, 1-16.

Said. J., Mahmudul A. M., Nik Abdullah. N.H. \& Zulkarnain N.N. (2016). Risk Management and Value Creation: Empirical Findings from Government Linked Companies in Malaysia. Review of European Studies. 8(2), 124-132

Schumpeter, J. (1934). The Theory of Economic Development, Cambridge, Mass: Harvard

University Press

Schwab, B. (1996). A note on ethics and strategy: do good ethics always make for good business? Strategic Management Journal, $17,499-500$

Thomas, A. B. (1988). Does leadership make a difference to organizational performance? Administrative Science Quarterly, 33(3), 388-400.

Trevino, L. K., \& Weaver, G. G. R. (2003). Managing ethics in business organizations: social scientific perspective. . Stanford, California: Stanford University Press. 
Wiklund, J., \& Shepherd, D. (2005). Entrepreneurial orientation and small business performance: a configurational approach. Journal of Business Venturing, 20(1), 71-91.

Zahra, S.A. (1991). Predictors and financial outcomes of corporate entrepreneurship: an exploratory study. Journal of Business Venturing, 6 (4), 259-285.

Zahra, S. A. (1993). A conceptual model of entrepreneurship as firm behavior: a critique and extension. Entrepreneurship theory and practice, 17, 5-5.

Zahra, S. A. (2005). Entrepreneurial risk taking in family firms. Family Business Review, 18(1), 23-40. 


\section{APPENDIX -A}

Table 6. Ethical Culture Measurements

My organisation makes it sufficiently clear to all level of employees on appropriate ethical conduct within the organisation.
My organisation sets a good example in terms of ethical behavior.
My organisation communicates the importance of ethics and integrity clearly and convincingly.
My organisation never authorise unethical or illegal conduct to meet business goals.
My organisation makes it sufficiently clear on how to use company equipment responsibly.
My organisation makes it sufficiently clear on how to use working hours responsibly.
My organisation makes it sufficiently clear on how to deal with conflicts of interests and sideline activities responsibly.

Table 7. Leadership qualities measurement

Top management of my organisation has ultimate responsibility for directing the affairs of the organisation, ensuring it is not in debt, well run and delivering the outcomes for which it has been set up.

Top management of my organisation has approved our mission and values and also has assessed all proposed activities against them.

Top management of my organisation focuses on the strategic direction of the organization.

Top management of my organisation has ultimate responsibility in finding ways to reduce cost of production or services.

Top management of my organisation has shown a love of self-improvement for themselves and their followers.

Top management of my organisation are empowering their followers to get things accomplished

Table 8. Entrepreneurship orientation measurement

My organistion is very proactive in introducing new products/services, administrative techniques or operating technologies.
My organisation typically adopts a very competitive approach.
My organisation has a strong tendency for high-risk projects (with chances of very high returns)
My organisation believes that, owing to the nature of the environment, bold, wide-ranging acts are necessary to achieve the
firms objectives
My organisation is actively searching for business opportunities.
My organisation typically adopts a bold, aggressive posture in order to maximise the probability of exploiting potential
opportunity.

Table 9. Innovation measurement

My organisation is adopting a proactive action in introducing products/services innovation.
My organisation is adopting a high level of organisational innovativeness.
My organisation is adopting a newness of approach that is executed to enter and exploit the targeted market.
My organisation is adopting process innovativeness such as the introduction of new production methods, new management
approaches, and new technologies that are used to improve production and management processes.
My organisation is adopting new competitive strategies that create value for the firm.
My organisation is adopting the introduction process of new products to the existing or new markets, through the combination
of strategic orientation with innovative behavior and process.

Table 10. Performance measurement

\begin{tabular}{l}
\hline Return on investment. \\
\hline Customer satisfaction. \\
\hline Customer retention. \\
\hline Product innovation. \\
\hline Firm growth. \\
\hline Profitability. \\
\hline Sales growth. \\
\hline Development of new products. \\
\hline
\end{tabular}




\section{NOTES}

